\title{
Antibacterial properties of rain tree (Albizia saman) and Mexican sunflower (Tithonia diversifolia) used as fodder in ruminant nutrition ${ }^{1 *}$ Ajayi, F. T. ${ }^{1}$ Omotoso, S. O. and ${ }^{2}$ Babayemi, O. J. \\ ${ }^{1}$ Institute of Agricultural Research and Training, Moor Plantation, P.M.B. 5029, Ibadan. \\ ${ }^{2}$ Department of Animal Science, University of Ibadan, Ibadan.
}

Abstract Corresponding author: festus2ajay@gmail.com; +2347039394840

Acetone and ethanol extracts of Albizia saman (ASL) and Tithonia diversifolia (TDL) leaves used as fodder for ruminant were evaluated for their antibacterial properties against selected pathogenic bacteria. Phytochemical screening was determined according to standard procedures, while antibacterial activity was by agar well diffusion and broth micro dilution methods. The levels of tannin (0.29 and $0.34 \mathrm{mg} / 100 \mathrm{~g})$; saponin (0.75 and $0.59 \mathrm{mg} / 100 \mathrm{~g})$; oxalates $(0.17$ and $0.14 \mathrm{mg} / 100 \mathrm{~g})$; and phytate $(0.11$ and $0.12 \mathrm{mg} / 100 \mathrm{~g})$ in the fodder plants were below critical levels that may affect digestibility in ruminants. Acetone and ethanol extracts from ASL and TDL showed maximum zones of inhibition against Staphylococcus aureus ( 19.00 and $14.50 \mathrm{~mm} ; 23.00$ and $21.50 \mathrm{~mm})$ and Pseudomonas aeruginosa $(15.50$ and $12.00 \mathrm{~mm} ; 18.50$ and $17.00 \mathrm{~mm})$, respectively compared to Gentamycin $(9.97 \mathrm{~mm})$. Minimum inhibitory concentration (MIC) values of acetone and ethanol extracts from ASL ranged from 0.10 to $0.28 \mathrm{mg} / \mathrm{mL}$ and 0.13 to $0.22 \mathrm{mg} / \mathrm{mL}$, while TDL extracts ranged from 0.20 to 0.32 $\mathrm{mg} / \mathrm{mL}$ and 0.20 to $0.31 \mathrm{mg} / \mathrm{mL}$, respectively for all the tested organisms. Minimum bactericidal concentration $(M B C)$ values of ethanol extracts from both plant ranged from 0.5-0.80 $\mathrm{mg} / \mathrm{mL}$ and $0.7-0.90 \mathrm{mg} / \mathrm{mL}$ compared to $\mathrm{MBC}$ values $(0.02-0.04 \mathrm{mg} / \mathrm{mL})$ of the reference antibiotic (gentamycin) for all the tested bacteria species. In conclusion, antibacterial properties exhibited by the plant extract implied that the bioactive compounds are potential antibacterial agents against pathogenic bacteria of ruminant or foodborne pathogens in vitro.

Keywords: Albizia saman, Antibacterial properties, bioactive compounds, Plant extracts, Tithonia diversifolia

\section{Introduction}

In Nigeria, ruminants depend mainly on natural grasses and legumes from marginal or degraded rangelands for their daily nutrient requirements for production or maintenance. Despite the low nutritional quality of the forages from natural pasture, they still remain an essential component of a successful ruminant production system. The special feeding behaviour (grazing or browsing nature) of ruminants and their preference for leaves from herbaceous plants, shrubs, and fodder trees enable them access to varieties of plant species which are of health importance. While extracts of most fodder plants are rich in secondary metabolites (e.g. phenolic compounds, essential oils and saponins), they have also been reported to have medicinal properties (Savithramma et al., 2011), either as antimicrobial drugs with reference to antibacterial agents or as alternatives to antibiotic growth promoter (Salem et al., 2012) in ruminant nutrition. It is no gainsaying that the bulk of animal protein consumed by most household in Nigeria is obtained from ruminants owned by the pastoral or sedentary livestock owners. However, in an attempt at providing a solution to the challenges of disease outbreak or spread of pathogenic bacterial infections among livestock, the use of synthetic antibiotics then becomes a routine practice. Although antibiotics have proven 
very effective in combating infectious diseases, overuse has become a major factor for the emergence of multiple drugresistant of microbial strains both in livestock and among consumers of animal products due to antibiotic residues (Harbottle et al., 2006; Franca et al., 2012). Hence, the negative consequences of antibiotics and changing patterns of antibacterial resistance necessitated an investigative search for antibacterial agents from fodder plants as alternative to the costly conventional antibacterial agents against selected pathogenic bacteria causing diseases in ruminants. Ethnoveterinary medicine has been an ancient medical practice by most livestock farmers in most African countries as an alternative to conventional drugs because of its greater accessibility, lower costs and apparent effectiveness (Mwale et al., 2005). In the same vein, Alhaji and Babalobi (2015) reported wide acceptance of Ethnoveterinary Medicine by small holder livestock keepers or Fulani pastoralists in Nigeria. However, the acceptance of ethnoveterinary practice as herbal remedies for prevention, control or treatment of different animal diseases in livestock health care system is premised on the held belief that they are more efficacious, in terms of broad spectrum of activities (Alhaji and Babalobi, 2015).

Albizia saman, formerly called Samanea saman (family: Leguminosae), and commonly called rain tree is a large size tree widely distributed in the humid and subhumid tropics. The pods and leaves are relished by ruminants (Babayemi et al., 2010). When fed to dairy cows, it increased weight gain and milk production (Roncallo et al., 2009). Tithonia diversifolia (Mexican sunflower) is a member of the family Asteracaea. It is an annual forb found growing aggressively on roadsides, cultivated farmlands, fallow land and river banks in Nigeria. The plant is highly adapted to moist soils, drought and heat tolerant up to the early dry season. Though largely considered as a weed, it is a plant with a wide range of uses and regarded as good ruminant fodder (Ekeocha, 2012).

Phytochemical screening of plant bioactive compounds and medicinal properties has been documented (Odeyemi et al., 2014). The potency of the bark decoction of these plants against a range of parasites in livestock (Liasu and Ogunkunle, 2007) and lowering of blood sugar in animals have also been reported. Escherichia coli, Staphylococcus aureus, Pseudomonas aeruginosa, and Salmonella typhi are pathogenic bacteria disease infections commonly found where intensive animal husbandry is practiced. They transmit diseases to livestock, causes production and economic losses to farmers. As pathogens of public health hazards, they are associated with foodborne infection and intoxication in human beings; for consumption of unhealthy animal products. Considering the above facts, this study was designed to evaluate quantitatively the phytochemicals and antibacterial properties of A. saman and T. diversifolia against Escherichia coli, Staphylococcus aureus, Pseudomonas aeruginosa, and Salmonella typhi.

\section{Materials and methods \\ Collection of plant materials}

Leaves from Albizia saman tree and Tithonia diversifolia were collected from a cultivated farmland within the Institute of Agricultural Research and Training, Moor Plantation, Ibadan, Nigeria. The leaves were harvested from a healthy and uninfected plant at 8-10 weeks of regrowth and washed thoroughly under a running tap water to remove dust and other foreign particles. Leaves were finally rinsed with sterile distilled water and thereafter, air dried under shade.

\section{Phytochemical analysis}

Phytochemical screening and identification 


\section{Ajayi, Omotoso and Babayemi}

of bioactive constituents in the plants under study were carried out according to standard procedures as described (Talukdar et al., 2010). One hundred (100) grams each of $A$. saman and $T$. diversifolia leaves were boiled with $200 \mathrm{ml}$ of solvent (n-hexane) for 1 hour. The extracts obtained were filtered through Whatman filter paper No.1, vacuum dried (on water bath at $40-50^{\circ} \mathrm{C}$ ) using a rotary evaporator and stored at 0 $4^{\circ} \mathrm{C}$ in air-tight containers for further use. The procedure was repeated three times.

Quantitative determination of phytochemicals

Phytochemicals in the crude extracts were quantified according to the following methods: tannin (Dawra, et al., 1988), phenols (Mc Donald et al., 2001), alkaloid (Harbone, 1973), saponin (Brunner, 1984), trypsin inhibitor (Liener, 1979), oxalate (Fasset, 1996), phytates(Maga, 1983),flavonoids (Chang et al., 2002), glycosides (Ferguson, 1956), steroids (Edeoga, et al., 2005), and terpenoids (Ferguson,1956).

Preparation of leaf extracts (acetone and ethanol)

One hundred grams each of $A$. saman and $T$. diversifolia leaves were ground separately into fine powder using a stainless steel grinder. Two hundred (200) $\mathrm{mL}$ each of $100 \%$ ethanol and acetone was added to each leaf sample and kept for 24 hours with periodic shaking (Puri, 1999). Ethanol and acetone fractions were separated by using sterile muslin cloth and then filtered through sterile Whatman filter paper (No. 2 ). The filtrates were later concentrated using a Rotary evaporator, collected and pooled. The procedure was repeated three times.

Source of test organisms and Standardization of microorganisms

The test organisms (Escherichia coli, Staphylococcus aureus, Pseudomonas aeruginosa and Salmonella typhi) were obtained from the stock culture of
Microbiology Laboratory, Institute of Agricultural Research and Training, Moor Plantation Ibadan, Nigeria. The Culture was standardized as described (NCCLS, 2002). About $0.2 \mathrm{~mL}$ of an 18-hour old culture of each bacterium was suspended into sterile universal bottles containing 20 $\mathrm{mL}$ nutrient agar and incubated for 5 hours at $37^{\circ} \mathrm{C}$ to obtain a logarithm growth phase. Normal saline was gradually added to compare its turbidity with McFarland Standard of 0.5 which correspond to approximately $1.0 \times 10^{8} \mathrm{CFU} / \mathrm{mL}$ as recommended by World Health Organization.

\section{Antibacterial activity}

Antibacterial activity of the leaf extracts was determined by the standard agar well diffusion method against E. coli, S. aureus, $P$. aeruginosa and S. typhi. Mueller Hinton agar was prepared to obtain standard bacterial stock suspension by mixing with crude extract $(30 \mathrm{mg})$ of acetone and ethanol dissolved in $1 \mathrm{~mL}$ of Di-methyl Sulphoxide (DMSO). Wells were made in each Mueller Hinton agar plates using sterile cork-borer $(5.0 \mathrm{~mm}$ diameter $)$. Thereafter, $1 \mathrm{~mL}$ of each plant extracts was introduced into the different wells; and the same volume of the respective medium was mixed with Gentamycin (control) and filled into the wells with micropipette. Three replicates were made for each extract against each of the test bacterium. The plates were kept for 6 hours at room temperature to allow for diffusion of the extract into the medium, after which they were incubated aerobically for $24 \mathrm{~h}$ at $37^{\circ} \mathrm{C}$. After incubation, the antibacterial activity of each plant extract and the control were assessed by measuring the zone of inhibition using a meter rule.

Determination of minimum inhibitory concentration (MIC) and minimum bactericidal concentration (MBC)

Minimum inhibitory concentration of leaf extract was determined by broth dilution 
method. Twenty percent (20\%) concentration of the extracts were prepared. About $0.1 \mathrm{~mL}$ of the concentration of the extract was put in test tubes and $2 \mathrm{~mL}$ of the nutrient broth was added. About $0.1 \mathrm{~mL}$ of the standard test organisms was also set up with Gentamycin. The tubes containing bacteria cultures were incubated at $37^{\circ} \mathrm{C}$ for 24 hours. The tube with the least concentration of extract which inhibited growth of the respective organism after incubation was recorded as the MIC. Minimum bactericidal concentration (MBC) was determined from each of the test tubes in the MIC determination. A loopful of broth was collected from those tubes that did not show any growth and inoculated onto a sterile nutrient agar by streaking. Nutrient agar plates were streaked with the respective test organisms to serve as controls. All the plates were incubated as previously stated and the concentration with no visible growth was inferred to be the MBC.

\section{Statistical analysis}

Data obtained for phytochemical constituents were subjected to Statistical Analyses using SPSS (Social Package for the Social Sciences), and values were presented as mean values along with their standard error of means, and Student's t-test was used to determine significant differences $(p<0.05)$ among the phytochemicals. P-values were regarded as not significant. Descriptive statistics were used for antibacterial properties (zones of inhibition) of leaf extracts on all the test organisms. Means, where significant, were separated using Least Significant Difference (LSD) tests at a level of 5\%. All analyses were done in triplicate.

\section{Results and discussion}

Phytochemicals and concentrations of leaf extract from plants

The results of the concentration of phytochemicals $(\mathrm{mg} / 100 \mathrm{~g})$ obtained from the leaves of $A$. saman and $T$. diversifolia are shown in Table 1. Alkaloids, tannin, saponin, phenol, flavonoids, and glycosides concentrations were 14.85 and 12.46 $\mathrm{mg} / 100 \mathrm{~g}, 0.29$ and $0.34 \mathrm{mg} / 100 \mathrm{~g}, 0.75$ and $0.59 \mathrm{mg} / 100 \mathrm{~g}, 0.25$ and $0.22 \mathrm{mg} / 100 \mathrm{~g}, 0.26$ and $0.32 \mathrm{mg} / 100 \mathrm{~g}, 0.39$ and $0.35 \mathrm{mg} / 100 \mathrm{~g}$, respectively. Higher content of alkaloids (14.85 and $12.45 \mathrm{mg} / 100 \mathrm{~g}$ ) was obtained in both plants. The phytochemicals from this study are similar to the type of bioactive compounds in plants reported (Edeoga et al., 2005) to play important roles as antimicrobial agents. High concentration of alkaloids obtained in this study is similar to the alkaloid concentration reported (Abukakar et al., 2008; Mariital et al., 2011) for Tamarindus indica and Morinda citrifolia leaf extracts, respectively.

The levels of tannin $(0.29$ and 0.34 $\mathrm{mg} / 100 \mathrm{~g}$ ) in this study were below the $5 \%$ critical level reported for browse plants that may affect digestibility in ruminant (Cooper and Owen-Smith, 1985). Although tannin gives rise to astringent sensation in the mouth and tends to reduce feed intake, the range $(0.29$ and $0.34 \mathrm{mg} / 100 \mathrm{~g})$ in this study is of no adverse effect on intake and digestibility in ruminants. Saponin, though a phytochemical with bitter principles, reduces the palatability of livestock feeds but exhibits hypocholesterolaemic activity and anti-inflammatory properties (Lewis and Elvin-Lewis, 1977).The levels of saponin $(0.75$ and $0.59 \mathrm{mg} / 100 \mathrm{~g})$ obtained were low to cause any detrimental effect on ruminant compared to the $3 \%$ forage saponin reported to have caused the death of grazing cattle (Oluremi et al., 2007).

The values of oxalate $(0.17$ and 0.14 $\mathrm{mg} / 100 \mathrm{~g}$ ) in this study were low compared to the range of oxalate $(0.3$ to $0.8 \mathrm{mg} / 100 \mathrm{~g})$ reported (Ajayi et al., 2009) for underutilized grain legume foliages in Nigeria. Similarly, the values of phytate $(0.11$ and $0.12 \mathrm{mg} / 100 \mathrm{~g}$ ) were also low to pose any threat to ruminants compared to the range 


\section{Ajayi, Omotoso and Babayemi}

(12.4-24.6 mg/100g) reported (Ajayi et al., 2009). Hence, the concentration of oxalate and phytate obtained from this study is suggestive of the bioavailability of calcium, magnesium, iron, and zinc to the animals.

Table 1: Phytochemical constituents of Albizia saman and Tithonia diversifolia leaf extracts

\begin{tabular}{|c|c|c|c|c|}
\hline $\begin{array}{l}\text { Phytochemicals } \\
(\mathrm{mg} / 100 \mathrm{~g})\end{array}$ & $\begin{array}{l}\text { Albizia saman } \\
\text { Mean } \pm \text { SEM }\end{array}$ & $\begin{array}{l}\text { Tithonia diversifolia } \\
\text { Mean } \pm \text { SEM }\end{array}$ & $\operatorname{Pr}>t$ & Remark \\
\hline Tannin & $0.286 \pm 0.001$ & $0.343 \pm 0.001$ & 0.0006 & $*$ \\
\hline Phenol & $0.255 \pm 0.002$ & $0.217 \pm 0.001$ & 0.0023 & $*$ \\
\hline Alkaloid & $14.85 \pm 0.010$ & $12.46 \pm 0.010$ & 0.0001 & $*$ \\
\hline Saponin & $0.747 \pm 0.002$ & $0.585 \pm 0.001$ & 0.0001 & $*$ \\
\hline Trypsin inhibitor( /mg) & $0.171 \pm 0.001$ & $0.160 \pm 0.000$ & 0.0082 & $*$ \\
\hline Oxalate & $0.165 \pm 0.001$ & $0.137 \pm 0.001$ & 0.0025 & $*$ \\
\hline Phytate & $0.113 \pm 0.0005$ & $0.124 \pm 0.0005$ & 0.0041 & $*$ \\
\hline Flavonoids & $0.260 \pm 0.000$ & $0.322 \pm 0.001$ & 0.0003 & $*$ \\
\hline Glycosides & $0.386 \pm 0.001$ & $0.347 \pm 0.001$ & 0.0008 & $*$ \\
\hline Steroids & $0.131 \pm 0.0005$ & $0.125 \pm 0.001$ & 0.0389 & $*$ \\
\hline Terpenoids & $0.116 \pm 0.000$ & $0.110 \pm 0.000$ & 0.0061 & $*$ \\
\hline
\end{tabular}

Notes: * Means are not significant, $\mathbf{S E M}=$ Standard error of mean.

Antibacterial activity of acetone and ethanol extracts of $A$. saman and $T$. diversifolia

The results of antibacterial activities of acetone and ethanol extracts of $A$. saman and $T$. diversifolia compared to the reference antibiotic (gentamycin) against the test bacterium as recorded from the zones of inhibition $(\mathrm{mm})$ are shown in Figures 1-4. Acetone and ethanol extracts of A. saman and T. diversifolia (Figure 1) displayed significant $(\mathrm{p}<0.05)$ antibacterial activity with zones of inhibition (5.5-8.0 $\mathrm{mm})$ against $E$. coli compared to gentamycin $(9.96 \mathrm{~mm})$. Leaf extracts of $A$. saman and $T$. diversifolia exhibited maximum activity $(\mathrm{p}<0.05)$ with zones of inhibition, ranged from 14.50 to $23.00 \mathrm{~mm}$ against $S$. aureus (Figure 2), ditto $P$. aeruginosa with the zones of inhibition of 15.50 and $12.00 \mathrm{~mm}$, and 18.50 and 17.00 $\mathrm{mm}$, respectively compared to gentamycin $(9.97 \mathrm{~mm})$ as shown (Figure 3). Gentamycin showed good activity $(\mathrm{p}<0.05)$ against $S$. typhi $(9.98 \mathrm{~mm})$ (Figure 4) than leaf extracts of $A$. saman and $T$. diversifolia, with the zones of inhibition ranged between 3.40 and $5.45 \mathrm{~mm}$, respectively.

From the present study, gentamycin (reference antibiotic) was more active against $E$. coli and $S$. typhi as recorded from the zones of inhibition (9.96 and $9.98 \mathrm{~mm}$ ), compared to leaf extract of $A$. saman and $T$. diversifolia. This finding is similar to the report of Abukakar et al. (2008). However, acetone and ethanol extracts from both plants still demonstrated considerable antibacterial activity against all the test organisms, considering the zones of inhibition of microbial growth as reported (Jegasser et al., 2011; Odeyemi et al., 2014) for leaf extracts of $A$. saman and $T$. diversifolia. In addition, the strong antibacterial activity against $S$. aureus and $P$. aeruginosa in this study agrees with the reports of Mariital et al. (2011) for $S$. multiflorus and A. nilotica leaf extracts.

The large zones of inhibition of ethanol and acetone extracts against $S$. aureus (14.50$23.00 \mathrm{~mm}$ ) and $P$. aeruginosa (12.00-18.50 $\mathrm{mm}$ ) recorded in this study is an indication of the high effectiveness of the plants. The antibacterial activities could be attributed to the high concentration and activities of alkaloids combined with other phytochemicals in the plant extracts. Essawi and Srour (2000) reported that optimal effectiveness of a medicinal plant is 
due to combined action of different compounds present in the plant, but not due to one main active constituent.

Flavonoids, in vitro form complexes with extracellular and soluble proteins and bacterial cell walls (Stewart and Beswick, 1979). Alkaloids have been reported to produce strong antimicrobial effects (Mariital et al., 2011), while steroids directly damage cell membranes with loss of cytoplasmic constituents (Smith and Shay, 1965). In addition, the degree of polarity of solvents of extraction into cell wall fractions of the plant could also be a reason for the varying significant differences observed in antibacterial activity between acetone and ethanol extracts, because antimicrobial bioactive compounds can partition exclusively in particular solvents (Cowan, 1999).

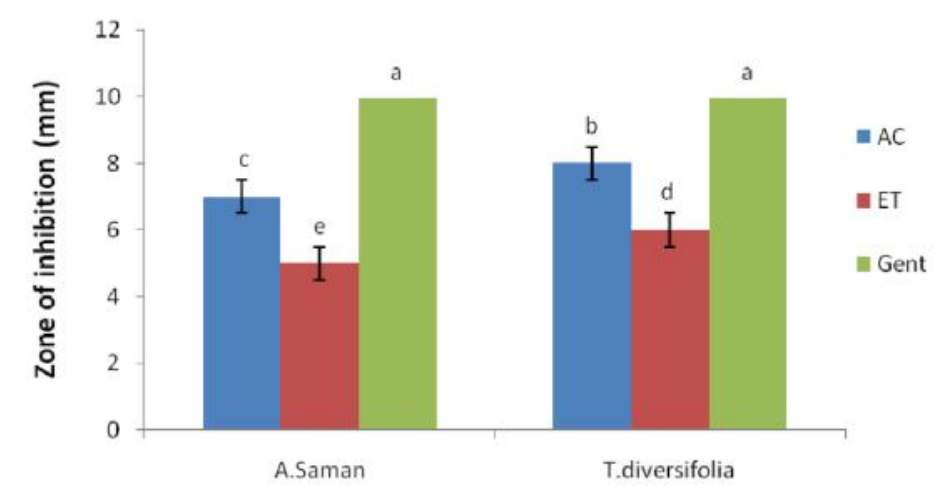

Figure 1. Antibacterial activity of leaf against Escherichia coli

$\mathrm{AC}=$ acetone, $\mathrm{ET}=$ ethanol, $\mathrm{Gent}=$ gentamycin

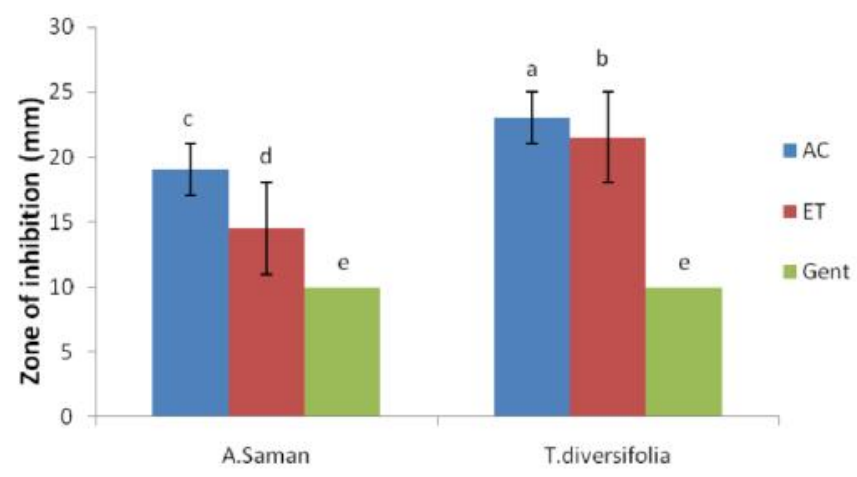

Figure 2. Antibacterial activity of leaf against Staphylococcus aureus

$\mathrm{AC}=$ acetone, $\mathrm{ET}=$ ethanol, $\mathrm{Gent}=$ gentamycin 
Ajayi, Omotoso and Babayemi

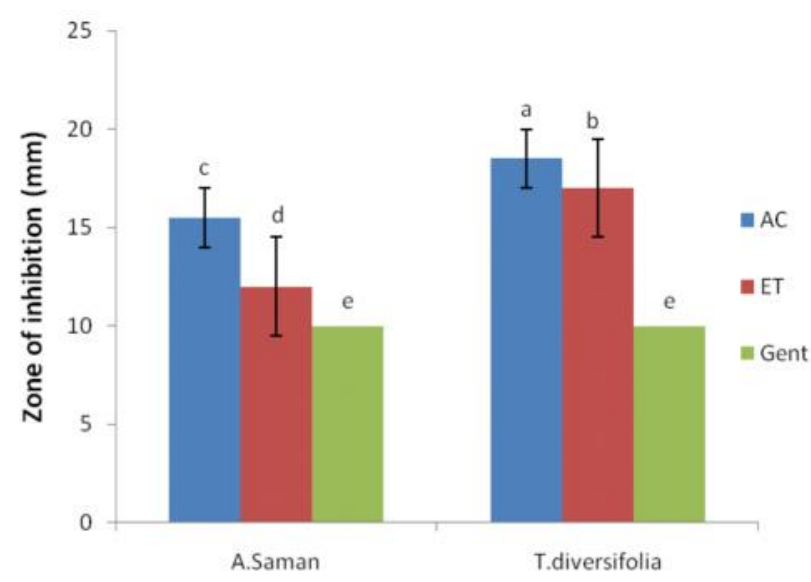

Figure 3. Antibacterial activity of leaf against Pseudomonas aeruginosa

$\mathrm{AC}=$ acetone, $\mathrm{ET}=$ ethanol, $\mathrm{Gent}=$ gentamycin

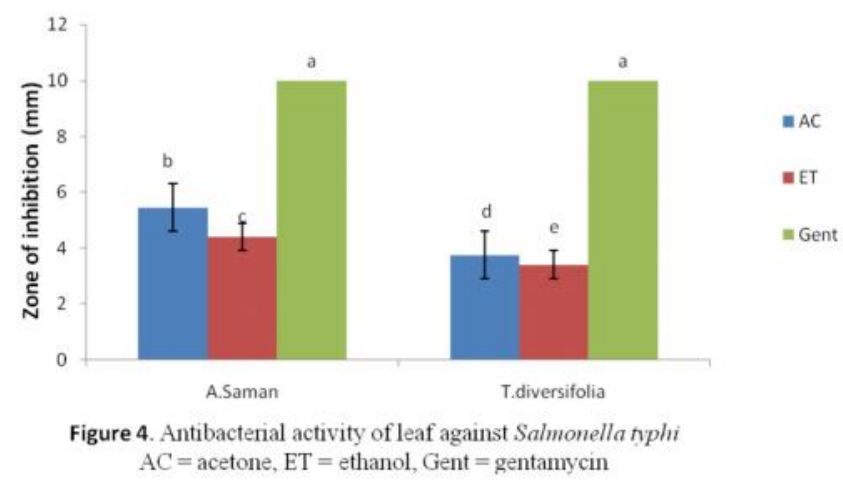

MIC and MBC of leaf extracts

Tables 2 and 3 showed the MIC and MBC of A. saman and $T$. diversifolia for $E$ coli, $S$. aureus, $P$. aeruginosa and $S$. typhi. The Minimum Inhibitory Concentration values for acetone extracts in A. saman and $T$. diversifolia ranged from 0.10 to $0.28 \mathrm{mg} / \mathrm{mL}$ and 0.20 to $0.32 \mathrm{mg} / \mathrm{mL}$, while values of ethanol extracts ranged from 0.13 to 0.22 $\mathrm{mg} / \mathrm{mL}$ and 0.20 to $0.31 \mathrm{mg} / \mathrm{mL}$, respectively. Leaf extracts from both plants exhibited strong inhibitory activities for all the test organisms, and this compared favourably with the reference antibiotic (gentamycin) with MIC values of 0.02-0.04 $\mathrm{mg} / \mathrm{mL}$ ).

Table 2: Minimum inhibitory concentration of $A$. saman and T. diversifolia leaf extracts

\begin{tabular}{|c|c|c|c|c|c|}
\hline \multirow[t]{2}{*}{ Fodder Plant } & \multirow[t]{2}{*}{ Extract } & \multicolumn{3}{|c|}{$\begin{array}{l}\text { Minimum inhibitory concentration }(\mathrm{mg} / \mathrm{mL}) \\
\text { Test organisms }\end{array}$} & \multirow[b]{2}{*}{ S. typhi } \\
\hline & & E. coli & S. aureus & P. aeruginosa & \\
\hline \multirow[t]{2}{*}{ Albiziasaman } & Acetone & 0.15 & 0.10 & 0.28 & 0.20 \\
\hline & Ethanol & 0.17 & 0.13 & 0.20 & 0.22 \\
\hline \multirow[t]{2}{*}{ Tithoniadiversifolia } & Acetone & 0.25 & 0.20 & 0.32 & 0.28 \\
\hline & Ethanol & 0.20 & 0.24 & 0.27 & 0.31 \\
\hline Gentamycin & & 0.04 & 0.03 & 0.03 & 0.02 \\
\hline DMSO & & 9.0 & 9.0 & 9.0 & 9.0 \\
\hline
\end{tabular}


Antibacterial properties of rain tree (Albizia saman) and Mexican sunflower (Tithonia diversifolia)

Table 3: Minimum bactericidal concentration of $A$. saman and $T$. diversifolia leaf extracts

\begin{tabular}{llllll}
\hline Fodder plant & Extract & \multicolumn{3}{c}{ Minimum bactericidal concentration $(\mathrm{mg} / \mathrm{mL})$} \\
& & \multicolumn{3}{c}{ Test organisms } \\
\cline { 3 - 6 } & & E. coli & S. aureus & P. aeurginosa & S. typhi \\
\hline Albiziasaman & Acetone & 0.80 & 0.55 & 0.82 & 0.80 \\
& Ethanol & 0.80 & 0.50 & 0.70 & 0.60 \\
Tithoniadivers & Acetone & 1.10 & 0.90 & 1.12 & 0.98 \\
ifolia & & & & 0.70 \\
& Ethanol & 0.90 & 0.70 & 0.80 & 0.02 \\
Gentamycin & & 0.04 & 0.03 & 0.03 & 9.0 \\
DMSO & 9.0 & 9.0 & 9.0 & \\
Note: DMSO = dimethyl-sulphoxide (dissolvent) &
\end{tabular}

Since the lowest MIC value required to inhibit growth of bacteria is an indicator of the efficacy of the plant extracts, therefore, results from this study indicated that all the MIC values from leaf extracts were within the reference range of MIC (0.05-0.50 $\mathrm{mg} / \mathrm{mL}$ ) inferred to be the strongest antibacterial activity (Diaz et al., 2010). Ethanol extracts of $A$. saman and $T$. diversifolia had varying bactericidal effect against all the tested organisms; in which $S$. aureus, has $\mathrm{MBC}$ of 0.50 and $0.70 \mathrm{mg} / \mathrm{mL}$, $S$. typhi $(0.60$ and $0.70 \mathrm{mg} / \mathrm{mL}), \quad P$. aeruginosa $(0.70$ and $0.80 \mathrm{mg} / \mathrm{mL})$, and $E$. coli $(0.80$ and $0.90 \mathrm{mg} / \mathrm{mL})$ respectively, while acetone extracts of $A$. saman and $T$. diversifolia has $\mathrm{MBC}$ of 0.55 and 0.90 $\mathrm{mg} / \mathrm{mL}$ against $S$. aureus, respectively. Irrespective of the solvents of extraction, the MIC and MBC values of $A$. saman and T. diversifolia demonstrated an outstanding activity against the test organisms. Nevertheless, the ability of both plant extracts to inhibit growth of $S$. aureus, $P$. aeruginosa, $S$. typhi and E. coli implied that $A$. saman and $T$. diversifolia leaves has antibacterial properties both for gram negative and gram positive bacteria, which is similar with the findings of other authors (Jegasser et al., 2011; Linthoingambi and Mutum, 2013). Therefore, the results from our study suggest that secondary metabolites in A. saman and $T$. diversifolia contained broad spectrum antibiotic compounds (Doughari, 2006) as reported for Tamarindus indica.

Furthermore, the variations in antibacterial activities observed in this study against $E$. coli, S. aureus, $P$. aeruginosa and S. typhi considering microbial growth inhibition, may be attributed to the nature of plant materials, different chemical characteristics of the bioactive compounds and polarity of solvents of extraction. In addition, species of bacteria and nature of their cell walls, as well as the interactions of plant bioactive compounds with membrane sterols in relation to pore formation on membranes (Rahman et al., 2010). Gramnegative bacteria have a more complex cell wall and an outer phospholipid membrane carrying the structural lipopolysaccharide components which make their cell wall impermeable to antimicrobial substances, while Gram-positive bacteria on the other hand, have only the outer peptidoglycan layer which is not an effective permeability membrane.

\section{Conclusion}

The study revealed that acetone and ethanol extracts of $A$. saman and $T$. diversifolia leave demonstrated considerable antibacterial activity against all the test organisms. Leaf extracts of both plants exhibited a higher degree of potency against Staphylococcus aureus and Pseudomonas aeruginosa compared to the 


\section{Ajayi, Omotoso and Babayemi}

reference antibiotic (gentamycin).Hence, extracts from any of the fodder plant contain antibacterial bioactive compounds that could potentially be used in livestock health care to control specific bacterial diseases of ruminant or foodborne pathogens in areas where intensive ruminant production is practiced.

\section{Competing Interests}

The authors declare that there are no competing interests.

\section{References}

Abukakar, M. G., Ukwani, A. N. and Shehu, R. A. 2008. Phytochemical screening and antibacterial activity of Tamarindus indica pulp extract. Asian Journal of Biochemistry, 3:134-138.

Ajayi, F. T., Akande, S. R., Adegbite,A.A. and Idowu, B. 2009. Assessment of seven under-utilized grain legumes foliages as feed resources for ruminants. Livestock. Res. for Rural $D e v$. 21 ( 9 ) http://www.lrrd.21/9/ajay21149.ht m, 25 May 2016.

Alhaji, N. B. and Babalobi, O. O. 2015. Participatory epidemiology of ethnoveterinary practices among Fulani Pastoralists used to manage c o n t a g i o s b o vi n e pleuropneumonia and other cattle ailments in Niger State. Nigerian Journal of Veterinary Medicine, $100 \quad p \quad p \quad$. http://dx.doi.org/10.1155/2015/460 408.

Babayemi, O. J., Iyang, U. A., Ifut, O. J. and Isaac, L. J. 2010. Nutritional value of cassava wastes ensiled with Albizia saman pods as feed for ruminants in off season. Agricultural Journal, 5: 220-224.

Brunner, J. H. 1984. Direct spectrophotometric determination of Saponin. Analytical Chemistry, 42: $1752-1754$.

Chang, C., Yang, M., Wen, H. and Chem, J. 2002. Estimation of total flavonoids contents in plants by two complementary colorimetric methods. Journal of $\quad F \quad o \quad o d$ Drug Analysis, 10: 178-182.

Cooper, S. M. and Owen-Smith, N. 1985. Condensed tannins deter feeding by browsing ruminants in a South African Savanah. Oecologia. (Berlin), 67:142- 146.

Cowan, M. M. 1999. Plant products as antimicrobial agents. Clinical Microbiology Rev.564-582.

Dawra, R. K., Makkar H. S. P., Singh B. 1988. Protein binding capacities of micro quantities of Tannins. Annals Biochem.170: 50-53.

Diaz, M. A. N., Rossi, C. C., Mendonca, V. R., Silva, D. M., Ribon, A. D. O. B., Aguilar, A. P. and Munoz, G. D. 2010. Screening of medicinal plants for antimicrobial activities on Staphylococcus aureus strains isolated from bovine mastitis. Brazilian Journal of Pharmacy. 20: 724-728.

Doughari, J. H. 2006. Antimicrobial activity of Tamarindus indica Linn. Tropical Journal of Pharm.Res.5: 592-603.

Edeoga, H. O., Okwu, D. E. and Mb a e bi e, B. O. 2005 . Phytochemical constituents of some Nigerian medicinal plants. African Journal of Biotechnology 4: 685688.

Ekeocha, A. H. 2012. Performance of growing West African Dwarf Ewe fed Mexican sunflower leaf meal based diets. Journal Recycle Adv. Agriculture, 1:69-76.

Essawi, T. and Srour, M. 2000. Screening of some Palestinian medicinal plants for antibacterial activity. 
Journal of Ethnopharmacology, 70: 343-349.

Fasset, D. W. 1996. Oxalates, In: Toxicants occurring naturally in foods. National Academy of Science Research Council, Washington D.C., USA.

Ferguson, N. M. 1956. A textbook of pharmacognosy. McMillan Company. New Delhi. 191.

Franca, C. A., Peixoto, R. M., Cavalcante, M. B., Melo, N. F., Oliveira C.J. B., Veshi, J. L. A., Mota, R. A. and Costa, M. M. 2012. Antimicrobial resistance of Staphylococcus spp. from small ruminant mastitis in Brazil. Pesq. Vet. Brasil, 32: 747-753.

Harbone, J. B. 1973. Phytochemical methods. A guide to modern techniques of plant analysis. Chapman and Hall., New York. pp. 267-270.

Harbottle, H., Thakur, S., Zhao, S. and White, D.G. 2006. Genetics of Antimicrobial resistance, Animal Biotechnology, 17 (2): 111-124.

Jegasser, R. C., Mars, A. and Gomathinayagam, S. 2011. Selective antimicrobial property of leaf extracts of Samanea saman against Candida albicans, Staphylococcus aureus and Escherichia coli using several microbial methods.Journal of American Science, 7: 108-114.

Lewis, W. H. and Elvin-Lewis, M. P. 1977. Medical botany plants affecting man's health. John Wiley and Sons., New York. Pp. 91- 93, 120-225 and 355-359.

Liasu, M. O. and Ogunkunle, A. T. J. 2007. Anatomy and secondary thickening pattern of the stem in Tithonia diversifolia (Hemsl). Advance Natural and Applied Science, 1:21-25.
Liener, I. E. 1979. Determination of antitryptic activity of soyabeans. Journal of Agricultural Science, 16: 602-609.

Lingthoigambi, W. and Mutum, S. Singh. 2013. Antimicrobial activities of different solvent extracts of Tithonia diversifolia (Hemsely A. Gray). Asian Journal of Plant Science Res.3: 50-54.

Maga, J. A. 1983. Phytate: its chemistry, occurrence, food interaction, nutritional significance and method of analysis. Journal of Agric. Food and Chem.30: 1- 9.

Mariital, R. M., Ogol, C. K. P. O., Oguge, N. O. and Okemo, P. O. 2011. Methanol extract of three medicinal plants from Samburu in Northern Kenya s h o w a n t i myocobacterial, antibacterial and antifungal properties. Research Journal of Medicinal Plant, 5: 5464.

Mc Donald, S., Prezier, P. D., Autovich, M. and Robards, K. 2001. Phenol contents and antioxidant activity of olive extracts. Journal of Food Chemistry, 73: 73-84.

Mwale, M., Bhebhe, E., Chimonyo, M. and Halimani, T. E. 2005. Use of herbal plants in poultry health management in the Mushagashe small-scale commercial farming area in Zimbabwe. International Journal of Applied Res. Veterinary Med. 3: 163-170.

National Committee for Clinical Laboratory Standards (NCCLS). 2002. Performance standard for antimicrobial disk and dilution susceptibility tests for bacterial isolated from animals: approved standard M31 - A2 $2^{\text {nd }}$ ed. National committee for Clinical Laboratory Standards, Wayne, PA, USA.

Odeyemi, A. T., Agidigbi, T. S., Adefemi, 


\section{Ajayi, Omotoso and Babayemi}

S. O. and Fasuan, S. O. 2014. Antimicrobial activities of crude extract of Tithonia diversifolia against common environmental pathogenic bacteria. International Journal Science.Technol. The Experiment, 20:1421-1426.

Oluremi, O. I. A., Ngi, J. and Andrew, I. 2007. Phytonutrient in Citrus fruit peel meal and nutritional implications for livestock production. Livestock Research for Rural Dev. 19: 345-346.

Puri, H. S. 1999. Neem (Azardirachta Indica), the divine tree. Hardwood Academic Publishers. The Netherlands.

Rahman, M. M., Richardson, A. and Azirun, M. S. 2010. Antibacterial activity of propolis and honey against Staphyloccus auruesand Escherichia coli. African Journal of Microbiological Res. 16: 1872-1878.

Roncallo, B., Torres, E. and Sierra, M. 2009. Produccion de vacas de doblepropositosuplementadas con frutos de Algarrobillo (Pithecellobium saman) d u r a n t e la s $11 \mathrm{uvi}$ a s : http://www.fao. org/ docrep /006/ Y4435S/y4435s00.htm\#Contents [ Consultado: 20/05/2009].
Salem, A. Z. M., Ronquillo, M., Camacho, L. M., Cerrillo, S .M. A., Dominguez, I . A . a n d Borquez, J. L. 2012. Beneficial effects of plant extracts in ruminant nutrition: A review. Indian Journal of Anim. Science, 82: 1117-1121.

Savithramma, N., Linga, R. M. and Ankanna. S. 2011. Screening of medicinal plants for secondary metabolites. Journal of Middle East Science. Res. 8:579- 584.

Smith, R. F. and Shay, D .E. 1965. Steroid lysis of protoplasts and effects of stabilizers and steroid antagonists. Applied and Environmental Microbiology13: 706-712

Stewart, F. S. and Beswick, T. S. 1979. Bacteriology, virology and immunity, $10^{\text {th }}$ edition. The English Language Book Society and BallierieTindall. London, pp. 35-37.

Talukdar, A. D., Choudhary, M. D., Chakraborty, M. and Dutta, B. K. 2010. Phytochemical screening and TLC profiling of plant extracts, Cyathea gigantean (Wall. Ex. Hook) Haltt and Cyathea brunoniana. Wall.ex.Hook. (Cl. and Bak.). Assam University Journal of Science and Technology: Biol. Environ. Sci. 5: 70-74.

Received: $17^{\text {th }}$ November, 2017

Accepted: $2^{\text {nd }}$ March, 2018 